Research Paper

\title{
Biofilm formation by Staphylococcus aureus from food contact surfaces in a meat-based broth and sensitivity to sanitizers
}

\author{
Evandro Leite de Souza ${ }^{1}$, Quênia Gramile Silva Meira ${ }^{1}$, Isabella de Medeiros Barbosa ${ }^{1}$, \\ Ana Júlia Alves Aguiar Athayde ${ }^{1}$, Maria Lúcia da Conceição ${ }^{1}$, José Pinto de Siqueira \\ Júnior $^{2}$ \\ ${ }^{1}$ Laboratório de Microbiologia de Alimentos, Departamento de Nutrição, Centro de Ciências da Saúde, \\ Universidade Federal da Paraíba, João Pessoa, PB, Brazil. \\ ${ }^{2}$ Laboratório de Genética de Microrganismos, Departamento de Biologia Molecular, Centro de Ciências \\ Exatas e da Natureza, Universidade Federal da Paraíba, João Pessoa, PB, Brazil.
}

Submitted: July 26, 2012; Approved: September 9, 2013.

\begin{abstract}
This study assessed the capacity of adhesion, the detachment kinetic and the biofilm formation by Staphylococcus aureus isolated from food services on stainless steel and polypropylene surfaces $(2 \mathrm{x}$ $2 \mathrm{~cm}$ ) when cultivated in a meat-based broth at 28 and $7{ }^{\circ} \mathrm{C}$. It was also to study the efficacy of the sanitizers sodium hypochlorite $(250 \mathrm{mg} / \mathrm{L})$ and peracetic acid $(30 \mathrm{mg} / \mathrm{L})$ in inactivating the bacterial cells in the preformed biofilm. S. aureus strains adhered in high numbers regardless the assayed surface kind and incubation temperature over $72 \mathrm{~h}$. Cells detachment of surfaces revealed high persistence over the incubation period. Number of cells needed for biofilm formation was noted at all experimental systems already after 3 days. Peracetic acid and sodium hypochlorite were not efficient in completely removing the cells of $S$. aureus adhered on polypropylene and stainless steel surfaces. From these results, the assayed strains revealed high capacity to adhere and form biofilm on polypropylene and stainless steel surfaces under different growth conditions. Moreover, the cells in biofilm matrix were resistant for total removal when submitted to the exposure to sanitizers.
\end{abstract}

Key words: Staphylococcus aureus, food processing environment, cross-contamination, biofilm, sanitizers.

\section{Introduction}

The surfaces that come into contact with foods are important sources for the transmission of microorganisms in food processing plants (BARNES et al., 1999). Many pathogenic or spoilage bacteria can be found attached to surfaces in the form of planktonic cells or sessile cells forming a biofilm (Braga et al., 2005). Biofilms are aggregates of microbial cells surrounded by a matrix of exopolymers, which confers resistance to these microorganisms (Costerton et al., 1999). Bacteria that aggregate to form biofilms are known to possess greater resistances to stress conditions than their planktonic counterparts, which are dispersed in the environment, including the susceptibility to sanitizers and other antimicrobials (Fux et al., 2004).
Early studies have found that bacterial adhesion and biofilm formation depend on the bacterial species, the nature of the surface, the growth medium and other environmental conditions (Malheiros et al., 2010; Oulahal et al., 2008).

To remove biofilm organisms, the solution of sanitization must penetrate the matrix of exopolymers and gain access to the microbial cells causing biofilm inactivation and removal. The oxidizing substances like chlorine or peracetic acid are frequently used for sanitizations of food processing plants. Peracetic acid may be used as a disinfectant because this agent decomposes into safe and environmental friendly residues (acetic acid and hydrogen peroxide), hence it can be applied without rinsing risks for food contamination by toxic residues and its efficacy is not affected by protein residues. Sodium hypochlorite $(\mathrm{NaClO})$ is

Send correspondence to E.L. Souza. Departamento de Nutrição, Centro de Ciências da Saúde, Universidade Federal da Paraíba, Campus I, 58051-900 Cidade Universitária, João Pessoa, PB, Brasil. E-mail: evandroleitesouza@ccs.ufpb.br. 
a chemical compound used for sanitization of food-contact surfaces (Meyer, 2003; Srey et al., 2012).

The formation of biofilms on the surfaces of food processing plants by pathogenic bacteria is a high risk source of cross-contamination because biofilm-adhering bacteria can detach during production and contaminate food as it passes over these surfaces. Staphylococcus aureus has been frequently found in food processing plants and is recognized as being responsible for outbreaks related to the consumption of fresh and processed foods worldwide (Rode $e t$ al., 2007).

The pathogenesis of the intoxication caused by $S$. aureus depends on the ability of the strain to survive, multiply under a variety of conditions and produce various extracellular compounds (Carson et al., 2002). The capability of S. aureus to adhere to and form biofilms enhances its survival and growth in food processing plants, providing a physiological advantage to $S$. aureus as the etiological agent of foodborne diseases (Herrera et al., 2007). Although some researchers have studied the ability of members of the Staphylococcus genera to adhere to and form biofilms (Kuzman et al., 2007; Møretro et al., 2003), most studies have addressed the clinical aspects related to biofilm formation by $S$. intermedius on medical implants and materials. Moreover, the few studies regarding the ability of $S$. aureus to form biofilms have employed standard type strains inoculated into synthetic media, and little is known about the ability of wild strains of S. aureus to adhere to and form biofilms when they are exposed to conditions simulating those environments found in food processing plants.

With regard to these aspects, this study assessed the capability of $S$. aureus cells from food processing plants to adhere to and form biofilms on polypropylene and stainless steel surfaces when cultivated in a meat-based broth under different temperatures. In addition, this study aimed to observe the effect of sanitizers on the reduction of viable cells in a biofilm matrix.

\section{Materials and Methods}

\section{Test strains}

S. aureus S3, S. aureus S28 and S. aureus S54 were obtained from the Microorganism Collection, Laboratory of Food Microbiology, Health Sciences Center, Federal University of Paraíba (João Pessoa, Brazil) and were used as the test microorganisms. These strains were isolated using standard procedures (Vanderzant and Splittsstoesser, 1992; Downes and Ito, 2001) from different surfaces of food processing plants of Food and Nutrition Services in the city of João Pessoa (Paraíba, Brazil). Stock cultures were maintained on nutrient agar (NA; Difco, Brazil) slants under refrigeration $\left(7 \pm 1^{\circ} \mathrm{C}\right)$.

Unless otherwise stated, the inocula used in the assays were obtained from cell suspensions grown to stationary phase and prepared by inoculating two colonies of each bacterium from overnight cultures, which were grown on Brain-heart infusion agar (Himedia, India), into $400 \mathrm{~mL}$ of Brain-heart infusion broth (Himedia, India), which was incubated at $37^{\circ} \mathrm{C}$ for $18 \mathrm{~h}$. After incubation, the bacteria were separated from the growth medium by centrifugation $(10,000 \times \mathrm{g})$ for $12 \mathrm{~min}$ at $4{ }^{\circ} \mathrm{C}$, washed twice with phosphate-buffered saline(PBS; pH 7.4), and resuspended in PBS. Suspensions were adjusted so that the optical density at $620 \mathrm{~nm}\left(\mathrm{OD}_{620}\right)$ of a 1-to-100 dilution was approximately 0.3 , which was approximately $10 \log$ colony forming units per milliliter $(10 \log \mathrm{cfu} / \mathrm{mL})$ (Carson et al., 2002). The suspensions were serially diluted in PBS $\left(10^{-1}-10^{-2}\right)$ to provide a viable cell count of approximately $8.0 \log \mathrm{cfu} / \mathrm{mL}$.

\section{Test surfaces and experimental conditions}

AISI 304 stainless steel $(2 \times 2 \times 0.2 \mathrm{~cm})$ and polypropylene coupons $(2 \times 2 \times 0.4 \mathrm{~cm})$ were used as the test surfaces. The coupons were individually cleaned, sanitized and sterilized according to a previously described procedure (Marques et al., 2007).

The adherence, detachment and biofilm formation of the test strains on the polypropylene and stainless steel surfaces, when inoculated into a meat-based broth, were assessed at two different incubation temperatures, 7 and $28{ }^{\circ} \mathrm{C}$.

\section{Preparation of the meat-based broth}

Bovine meat steaks were trimmed of all external fat and cut into pieces of a uniform size $(3 \times 3 \times 3 \mathrm{~cm})$. The meat pieces were boiled in distilled water for $20 \mathrm{~min}$. Approximately $500 \mathrm{~mL}$ of meat broth was obtained and vacuum filtered using Whatman $\mathrm{n}^{\circ} 1$ filter paper, and the filtrate was sterilized by autoclavation for $15 \mathrm{~min}$ (1.21 atm). The obtained broth was stored at $-20{ }^{\circ} \mathrm{C}$ in aliquots of $50 \mathrm{~mL}$, and when required, one aliquot was thawed under refrigeration $\left(7 \pm 1{ }^{\circ} \mathrm{C}\right)$ and used for the experimental analysis.

The meat broth was characterized with regard to its physico-chemical characteristics (acidity, moisture, protein, fat, carbohydrate, mineral content and $\mathrm{pH}$ value) according to standard procedures. The physico-chemical characteristics for the meat broth used in the assays are shown in Table 1.

\section{Adhesion to surfaces and quantification of adhered cells}

An aliquot of $100 \mu \mathrm{L}$ of the growth media was mixed into $50 \mu \mathrm{L}$ of the bacterial inoculum (initial amount of bacterial cells in the system, c.a. $10^{6} \mathrm{cfu}$ ), plated onto the center of each coupon and incubated under the pre-established temperatures. After 24, 48 and $72 \mathrm{~h}$ of incubation, coupons (four for each treatment) were withdrawn and immersed in sterile peptone water (SPW; $0.1 \mathrm{~g} / 100 \mathrm{~mL}$ ) for $15 \mathrm{~s}$ to release the non-adherent cells. The cells adhered to the coupons were collected by thoroughly rubbing the surfaces 
Table 1 - Physico-chemical characteristics of meat-based broth.

\begin{tabular}{lc}
\hline Physico-chemical parameters & Amounts \\
\hline Protein & $0.96 \mathrm{~g} / 100 \mathrm{~g}$ \\
Fat & $0.43 \mathrm{~g} / 100 \mathrm{~g}$ \\
Moisture & $97.75 \mathrm{~g} / 100 \mathrm{~g}$ \\
Carbohydrates & $0.65 \mathrm{~g} / 100 \mathrm{~g}$ \\
Ashes & $0.21 \mathrm{~g} / 100 \mathrm{~g}$ \\
$\mathrm{pH}\left(\mathrm{T}: 25^{\circ} \mathrm{C}\right)$ & 6.21 \\
\hline
\end{tabular}

with two moistened swabs, which were resuspended in SPW by vigorously vortexing for $30 \mathrm{~s}$. The mixture was serially diluted $\left(10^{-1}-10^{-5}\right)$ in SPW, and aliquots of $100 \mu \mathrm{L}$ were spread plated onto sterile NA plates. The plates were incubated for $24 \mathrm{~h}$ at $37{ }^{\circ} \mathrm{C}$ (Herrera et al., 2007; Rode et al., 2007). After the incubation period, the number of viable cells was counted, and the results were expressed in $\log$ $\mathrm{cfu} / \mathrm{cm}^{2}$.

\section{Detachment of adhered cells}

An aliquot of $100 \mu \mathrm{L}$ of the growth media was mixed into $50 \mu \mathrm{L}$ of the bacterial inoculum (initial amount of bacterial cells in the system, $10^{6} \mathrm{cfu}$ ) and plated onto the center of each coupon, followed by incubation under the preestablished temperatures. After 24, 48 and $72 \mathrm{~h}$ of incubation, the coupons (four for each treatment) were withdrawn and immersed in SPW for $15 \mathrm{~s}$ to release the non-adherent cells. Each coupon was placed on a sterile NA plate and, after $2 \mathrm{~min}$, was removed and placed onto a second sterile NA plate. This procedure was repeated through 7 sterile NA plates. The numbers of detached cells on the NA plates, using an order number of 1, 2, 3, 4, 5, 6, and 7, were found by transferring the agar blotted from each plate to $10 \mathrm{~mL}$ of SPW followed by blending using a stomacher. The mixture was serially diluted $\left(10^{-1}-10^{-5}\right)$ in SPW, and aliquots of $100 \mu \mathrm{L}$ were spread plated onto NA plates. The plates were incubated for $24 \mathrm{~h}$ at $37^{\circ} \mathrm{C}$ (Herrera et al., 2007). After the incubation period, the number of viable cells was counted, and the results were expressed in $\log \mathrm{cfu} / \mathrm{cm}^{2}$.

\section{Biofilm development and quantification}

The level of biofilm formation by $S$. aureus S3 on polypropylene and stainless steel surfaces incubated in meat broth at $7^{\circ} \mathrm{C}$ and $28^{\circ} \mathrm{C}$ over 15 days was assessed. For this experiment, eight stainless coupons and eight polypropylene coupons were immersed in sterile petri dishes containing $20 \mathrm{~mL}$ of the growth media and $2 \mathrm{~mL}$ of the bacterial inoculum (initial inoculum, approximately $10^{7}$ $\mathrm{cfu} / \mathrm{mL}$ of meat broth). The petri dishes were sealed and statically incubated at the pre-established temperatures. After 3, 6, 9, 12 and 15 days of incubation, the coupons were withdrawn and washed with SPW to remove the nonadherent cells. The coupons were then again immersed in fresh media containing the same amount of inoculum. Because the process was repeated four times, the experiment required a 15-day period.

At each incubation interval, four coupons for each treatment were submitted for bacterial counts from their biofilm matrices. For these counts, the biofilm was scraped with two moistened sterile swabs, which were resuspended in $9 \mathrm{~mL}$ of SPW by vortexing for $30 \mathrm{~s}$. Serial dilutions were prepared in SPW, and aliquots of $100 \mu \mathrm{L}$ were spread plated onto sterile NA plates and then incubated at $37^{\circ} \mathrm{C}$ for 24 h (Marques et al., 2007; Meira et al., 2012). After the incubation period, the number of viable cells was counted, and the results were expressed in $\log \mathrm{cfu} / \mathrm{cm}^{2}$.

\section{Sanitizer application}

The efficacy of the sanitizers sodium hypochlorite $(25 \mathrm{~mL} / \mathrm{L})$ and peracetic acid $(30 \mathrm{~g} / \mathrm{L})$, which are the concentrations these sanitizers commonly applied for disinfecting surfaces in food processing plants, were assessed for their ability to remove $S$. aureus $\mathrm{S} 3$ cells from a biofilm matrix grown in the meat-based broth at 7 and $28^{\circ} \mathrm{C}$. For this experiment, five coupons were allowed to develop biofilms under the experimental conditions cited above. After 15 days of incubation, the coupons were washed in SPW and immersed for $30 \mathrm{~s}$ in sterile petri dishes containing $20 \mathrm{~mL}$ of the sanitizer solution (18). The coupons were then withdrawn from the sanitizer solution and immersed for $3 \mathrm{~s}$ in a neutralizing solution $\left(0.1 \mathrm{M} \mathrm{Na}_{2} \mathrm{~S}_{2} \mathrm{O}_{3}\right)$. The remaining cells were counted after scraping, which employed two sterile moistened swabs. The swabs were then vigorously resuspended by vortexing them in $9 \mathrm{~mL}$ of SPW. Serial dilutions were prepared in SPW, and aliquots of $100 \mu \mathrm{L}$ were spread plated onto NA plates and incubated at $37^{\circ} \mathrm{C}$ for $24 \mathrm{~h}$ (Ammor et al., 2004). After the incubation period, the number of viable cells was counted, and the results expressed in $\mathrm{cfu} / \mathrm{cm}^{2}$. In control assays, the sanitizer solutions were replaced with sterile distilled water. The efficiency of each sanitizer was calculated with regard to the difference between the counts obtained for the control surfaces and for the surfaces exposed to the sanitizers.

\section{Procedures for scanning electron microscopy}

Samples were submitted to biofilm formation on the polypropylene and stainless steel surfaces $\left(28^{\circ} \mathrm{C}\right)$, according to the already cited procedure, and after exposure to the sanitizers or distilled water, the samples were observed for remaining viable cells in the biofilm matrix using scanning electron microscopy. The coupons were pre-fixed with glutaraldehyde $(2 \mathrm{~mL} / 100 \mathrm{~mL})$ for $2 \mathrm{~h}$ at $4{ }^{\circ} \mathrm{C}$ and postfixed with osmium tetroxide $(2 \mathrm{~g} / 100 \mathrm{~mL})$ for $30 \mathrm{~min}$ at $30{ }^{\circ} \mathrm{C}$. Afterward, the cells were washed twice with PBS, dried at a critical point in liquid $\mathrm{CO}_{2}$ under 95 bar of pressure, gold covered (fine coat ion sputter JFC-1100, JEOL Ltd., Tokyo, Japan) and examined using a scanning elec- 
tron microscope (FEI QUANTA 200F) as previously described (Kumar and Anand, 1998; Zoltai et al., 1981).

\section{Reproducibility and statistics}

All assays were performed in triplicate on three separate occasions, and the results are expressed as averages for each of the assays. Counts were converted to decimal logarithmic values $\left(\log \mathrm{cfu} / \mathrm{cm}^{2}\right)$ to match the assumption of a normal distribution. Counts obtained for adhesion, detachment and biofilm formation were submitted to an analysis of variance (ANOVA) followed by Duncan's test to determine whether the incubation temperature and contact surface had a significant influence. Counts obtained for the effect of the sanitizers (before and after the application) on the biofilm matrix were compared using a paired Students t-test. Data were analyzed using the software Statistica 7. A probability value of $\mathrm{p}<0.05$ was accepted to indicate a significant difference.

\section{Results and Discussion}

A meat-based broth and two incubation temperatures ( 7 and $28^{\circ} \mathrm{C}$ ) were tested with regard to their possible influence on cell adherence and biofilm formation by $S$. aureus to polypropylene and stainless steel surfaces. The temperatures 7 and $28^{\circ} \mathrm{C}$ were chosen because these are the typical temperature used to store pre-prepared meat products and the common temperature found in rooms used by Brazilian food service agencies, respectively. With regard to the nutrient availability in foods and bacterial interactions with their surrounding environment, some researchers have proposed the use of a liquid food-based media as a substrate for assessing microbial growth (in a planktonic or sessile form) because this medium may be useful for obtaining more realistic results, as compared with the use of a laboratory broth (Herrera et al., 2007).

The number of $S$. aureus S3, S28 and S54 cells adhered to polypropylene and stainless steel surfaces over $72 \mathrm{~h}$ of incubation at 7 and $28^{\circ} \mathrm{C}$ is shown in Figure 1 . The highest numbers of adhered cells $\left(5-6 \log \mathrm{cfu} / \mathrm{cm}^{2}\right)$ on the polypropylene and stainless steel surfaces over $72 \mathrm{~h}$ were found for $S$. aureus S54 in all experimental systems. The counts of adherent $S$. aureus S3 cells were about $5 \mathrm{log}$ $\mathrm{cfu} / \mathrm{cm}^{2}$ over the evaluated time intervals. However, for $S$. aureus S28, the counts were in the range of $4-5 \log \mathrm{cfu} / \mathrm{cm}^{2}$.

S. aureus S3 and S54 presented a similar pattern of adhesion, with similar bacterial counts over the three assessed time intervals. At both tested temperatures, $S$. aureus S28 displayed a clear two phase adhesion pattern on the stainless steel coupons, with an initial increase in the number of adherent cells up to 5 and $5.9 \log \mathrm{cfu} / \mathrm{cm}^{2}$ at 7 and $28{ }^{\circ} \mathrm{C}$, respectively. This increase was followed by a decrease at $72 \mathrm{~h}$ to 4.8 and $4.9 \log \mathrm{cfu} / \mathrm{cm}^{2}$ at 7 and $28^{\circ} \mathrm{C}$, respectively. Herrera et al. (2007) noted a similar behavior with $S$. aureus growing in a phosphate buffer solution (mimicking a nutrient-lacking media) over $25 \mathrm{~h}$ at $25^{\circ} \mathrm{C}$. These findings suggest that under static conditions, adherent cells may be present in high numbers but do not always increase over time.

No significant influence $(\mathrm{p}>0.05)$ of surface type or incubation temperature on the adherence of $S$. aureus S3 and S54 was noted. For S. aureus S28, a significantly greater number $(\mathrm{p}<0.05)$ of adherent cells was found on the stainless steel surface at $28^{\circ} \mathrm{C}$, with respect to $7{ }^{\circ} \mathrm{C}$. Otherwise, the number of adherent $S$. aureus $\mathrm{S} 28$ cells on polypropylene did not differ $(\mathrm{p}>0.05)$ at 28 and $7{ }^{\circ} \mathrm{C}$. In cultivating cells in tryptic soy broth at sub-optimal temperatures $\left(20,25\right.$ and $\left.30^{\circ} \mathrm{C}\right)$, Rode et al. (2007) found the highest attachment capacity with $S$. aureus on polystyrene. To the contrary, Morton et al. (1998) found that, regardless of the species or assayed surface, bacterial adhesion occurs at a maximal intensity when the bacteria are allowed to grow at their optimal temperature.

Cell detachment (kinetics of the detachment) from the polypropylene and stainless steel surfaces for $S$. aureus $\mathrm{S} 3$, $\mathrm{S} 28$ and S54 at 7 and $28{ }^{\circ} \mathrm{C}$ are displayed in Figure 2. The bacterial counts revealed a linear decrease in the detachment rate over the contact sequence in all the experimental systems. Cell detachment was at least $3 \log \mathrm{cfu} / \mathrm{cm}^{2}$ during

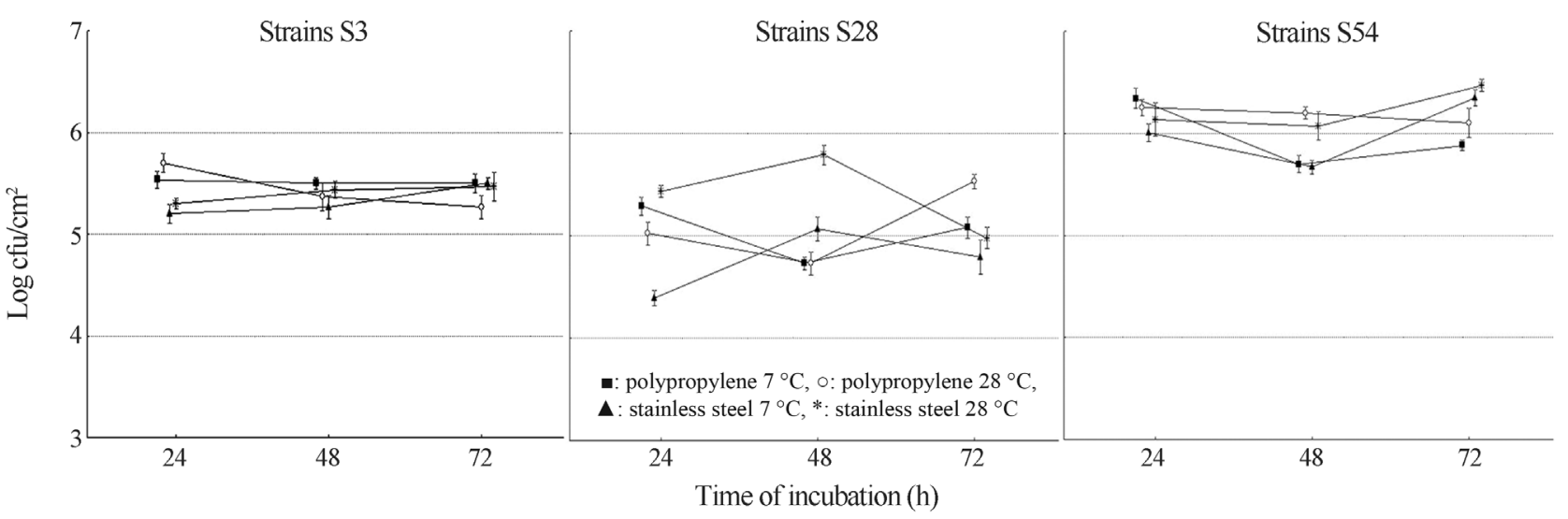

Figure 1 - Kinetics of adhesion of S. aureus S3, S28 and S5 cells to polypropylene and stainless steel surfaces in meat-based broth at $7{ }^{\circ} \mathrm{C}$ and $28^{\circ} \mathrm{C}$. 
Strains S3

Strains S28

Strains S54
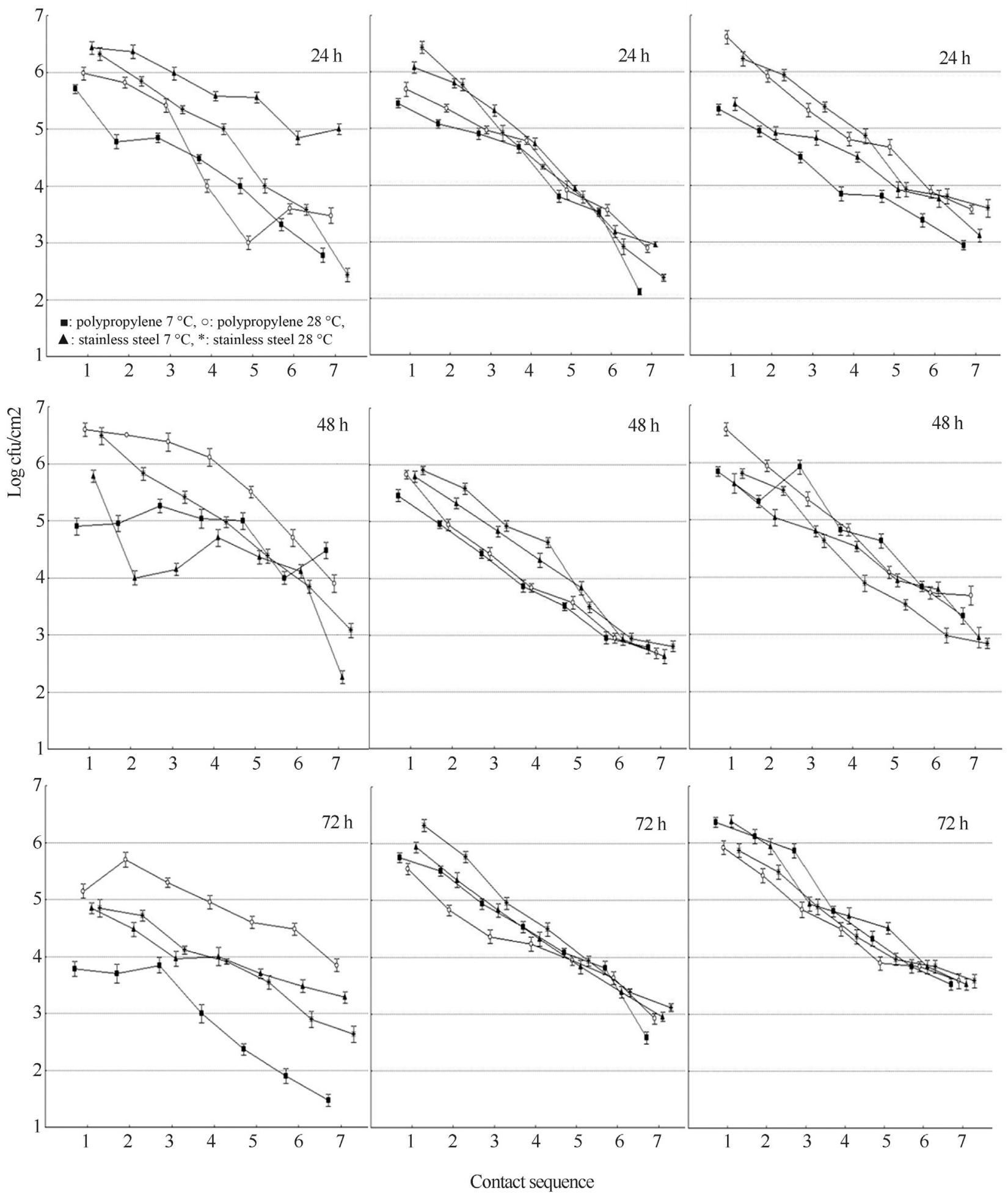

Figure 2 - Kinetics of separation of S. aureus S3, S28 and S5 cells after 24, 48 and 72 hours of polypropylene and stainless steel surfaces in meat-based broth at $7{ }^{\circ} \mathrm{C}$ and $28^{\circ} \mathrm{C}$.

the first 6 contacts (blot order) for most systems, suggesting a cell high persistence on the surfaces over $72 \mathrm{~h}$.

No significant influence $(p>0.05)$ for surface type or incubation temperature was noted for the detachment rate of S. aureus S28 and S54 over the evaluated incubation times. After $24 \mathrm{~h}$ of incubation, the highest numbers ( $\mathrm{p}<0.05$ ) of detached $S$. aureus S3 cells were found for stainless steel at $7^{\circ} \mathrm{C}$, while after 48 and $72 \mathrm{~h}$, the highest 
counts $(\mathrm{p}<0.05)$ were noted for polypropylene at $28^{\circ} \mathrm{C}$. Rossoni and Gaylarde (2000) states that stainless steel is more easily disinfected compared to polyethylene; however studies performed with different types of stainless steel that have undergone a corrosion process indicate an increase in bacterial adhesion. Stainless steels although more resistant than others surfaces used for processing food (due to their chemical and mechanical/physical stability at various food-processing temperatures, cleanability and high resistance to corrosion), has been noted to suffer pitting and formation of local deep pits on these free surfaces, because for example the liberation of free chlorine from the use of chlorine compounds used in sanitization processes, thereby facilitating bacterial adhesion and biofilm formation (Zottola and Sasahara, 1994; Van Houdt and Michiels, 2010).

These data, regarding the detachment of $S$. aureus cells over a significant number of contacts to the blot agar, suggest a high-risk source for the cross-contamination of foods as they come into contact with contaminated surfaces. The cells released from adhered-cells aggregates or biofilms retain its high level of resistance to antimicrobial agents, and may contain sufficient numbers of bacteria to represent a potential infectious dose. Thus, it is assumed that adhered-cells aggregates or biofilm formation can mean a potential risk for food cross-contamination, especially if contamination of the food occurs after an operation or bactericidal treatment (Spoering and Lewis, 2001; Fux et al., 2004; Meira et al., 2012).

The maturation of a bacterial biofilm occurs between three to six days after the initial adhesion, and only after 10 days is an increased population density with a pronounced production and deposition of exopolysaccharide reached (a mature biofilm) (Cheng et al., 2007; Heydorn et al., 2000).
Levels of biofilm formation by $S$. aureus $\mathrm{S} 3$ on polypropylene and stainless surfaces over 15 days and under different experimental conditions are shown in Figure 3. These results indicated a similar capability $(\mathrm{p}>0.05)$ for biofilm formation when the strain was submitted to the different combinations of surface types and growth temperatures. For most systems, the maximum number of cells (6-7 log $\mathrm{cfu} / \mathrm{cm}^{2}$ ) was found after six days of incubation, followed by a linear decrease in the remainder of the assessed time intervals.

The bacterial counts indicated biofilm formation on both surfaces at 7 and $28^{\circ} \mathrm{C}$ after 3 days. A number of viable cells, from $5-7 \log \mathrm{cfu} / \mathrm{cm}^{2}\left(10^{5}\right.$ to $\left.10^{7} \mathrm{cfu} / \mathrm{cm}^{2}\right)$, is required for biofilm formation, and lower values could indicate an adhesion process (Ronner and Wong, 1993; Wirtanen et al., 1995). The highest intensity of biofilm formation on the stainless steel and polypropylene surfaces was found at $28^{\circ} \mathrm{C}$. Malheiros et al. (2010) studying the adherence of $S$. aureus on polyethylene and stainless steel surfaces noted increase in counts of adhered cells at $20{ }^{\circ} \mathrm{C}$ in comparison to lower incubation temperatures $(7,10,12$ and $15^{\circ} \mathrm{C}$ ). Previous studies also showed that regardless the microbial specie or assayed surface, the adhesion process occurs at maximum intensity when bacteria are kept next to or at their optimum growth temperature (Morton et al., 1998; Kusumaningrum et al., 2003; Malheiros et al., 2010).

Marques et al. (2007) studied biofilm formation by $S$. aureus on stainless steel and glass surfaces immersed in $\mathrm{BHI}$ and determined bacterial counts of 7 and $8 \log \mathrm{cfu} / \mathrm{cm}^{2}$, respectively, after 15 days of incubation. Oulahal et al. (2008) assessed the survival of $S$. aureus on artificially contaminated stainless steel and polypropylene surfaces immersed in dairy products (pasteurized skim milk, raw milk and cheese curd) at $12{ }^{\circ} \mathrm{C}$ and $25^{\circ} \mathrm{C}$ and observed that the

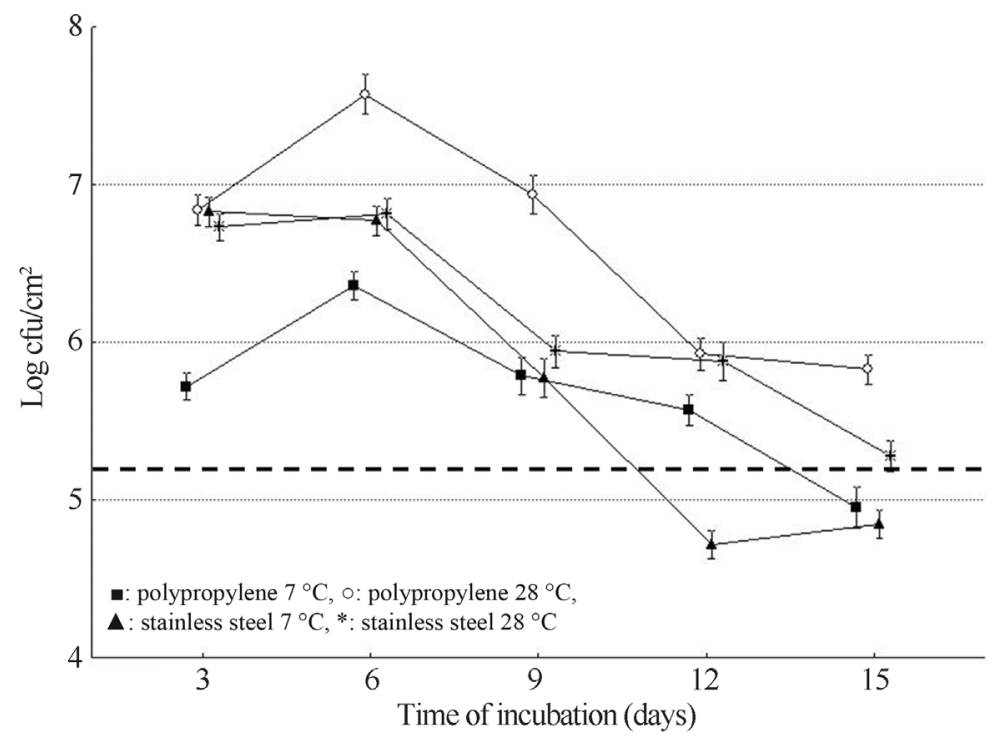

Figure 3 - Biofilm formation by S. aureus $\mathrm{S} 3$ cells on polypropylene and stainless steel surfaces in meat-based broth at $7{ }^{\circ} \mathrm{C}$ and $28^{\circ} \mathrm{C}$ over 15 days of incubation. Dotted line means the lower bacterial count $\left(\mathrm{cfu}^{\mathrm{c}} \mathrm{cm}^{2}\right)$ needed for biofilm formation according to Ronner et al. (1993) and Wirtanen et al. (1995). 
cells remained viable on these surfaces for 8 days. These authors suggested that bacterial survival might be related to the possible formation of a biofilm during the incubation period.

Counts of $S$. aureus $\mathrm{S} 3$ adhered to polypropylene and stainless surfaces after the application of peracetic acid and sodium hypochlorite are shown in Table 2. The log reduction caused by peracetic acid ranged from 2.6 to $3.7 \log \mathrm{cfu} / \mathrm{cm}^{2}$, while for sodium hypochlorite, the reduction was 1.9-2.7 $\log \mathrm{cfu} / \mathrm{cm}^{2}$. However, in all the experimental systems, both tested sanitizers largely decreased $(p<0.05)$ the counts of cells adhered to the assayed surfaces.

The electron microphotography of the polypropylene and stainless steel surfaces after the application of the sanitizers, sodium hypochlorite and peracetic acid, is shown in Figure 4. The findings for the electron microscopy are in accord with the results obtained from the analysis of the viable cell counts on the surfaces when some remaining cells were found after applying peracetic acid (Figure 4 - B and E) and sodium hypochlorite (Figure 4 - C and F). The obtained results indicate that the sanitizers, peracetic acid $(30 \mathrm{mg} / \mathrm{L})$ and sodium hypochlorite $(250 \mathrm{mg} / \mathrm{L})$, were not efficient in completely removing the $S$. aureus cells adhered to the polypropylene and stainless steel surfaces. Residual cells adhered to the surfaces after the application of these sanitizers reinforce the biofilm as a likely source of cross-contamination in food processing plants. Meira et al. (2012) also found results similar to those found in this study when studied biofilm formation on stainless steel and polypropylene surfaces, where they found that peracetic acid and sodium hypochlorite were not efficient in completely removing the cells of biofilm of $S$. aureus under the same conditions used in this study.

The real quantification of the microorganisms adhered to the surfaces, both before and after the disinfection procedure, is still not a completely solved problem, making it difficult to choose a reliable and effective method. There are publications on methods to quantify cells attached to inert materials, including swabbing (Herrera et al., 2007; RODE et al., 2007), impedance measurements (Asseré et al., 2008; Revol-Junelles et al., 2005) and real-time PCR (Bruhn et al., 2006). However, impedance measurements and real-time PCR are still only considered for usage in in vitro studies (Asseré et al., 2008). Swabbing, the oldest method, is still the main method employed in field studies; however, this method is known to not detach all microorganisms (Midelet and Carpentier, 2002). The removal efficiency of the swabbing procedure depends on several aspects. For instance, regarding the swab material, cotton swabs are better at removing adhered cells than polyester and rayon swabs. Moreover, using a moistened swab is more efficient than a dry one, and multiple swabbings may be performed at the same location (Asseré et al., 2008; Rose et al., 2004). All these concerns were considered in our study to increase the efficiency of the swabbing procedure, providing a real estimation of the surface-adhered cell population.

With regard to the limitations of this study in assessing the adhesion, detachment and biofilm formation of a monospecies inoculum under static conditions, there are clear implications for our results in designing strategies to control cross-contamination in the food service industry because the strains utilized as the test microorganisms were directly isolated from food contact surfaces and because the assays were performed with materials (surfaces) that are commonly used in food processing when the materials are immersed in a food-based media. These results are encouraging for further studies focusing on the capacity of these strains to adhere to, detach and form biofilms on the surfaces of equipment and utensils used in the food service industry under continuous flux and for the efficacy of differ-

Table 2 - Effects of peracetic acid (30 mg/L) and sodium hypochlorite $(250 \mathrm{mg} / \mathrm{L})$ on the count $\left(\log \mathrm{cfu} / \mathrm{cm}^{2}\right)$ of $S$. aureus $\mathrm{S} 3$ cells (grown in meat-based broth at 7 and $28^{\circ} \mathrm{C}$ ) forming a 15 -days biofilm onto polypropylene and stainless steel surfaces.

\begin{tabular}{|c|c|c|c|c|}
\hline Sanitizers & Temperature & Control & Treated & Fraction reduction* \\
\hline \multicolumn{5}{|l|}{ Polypropylene } \\
\hline Peracetic acid & $7^{\circ} \mathrm{C}$ & $6.1( \pm 0.2)^{\mathrm{a}}$ & $2.4^{\mathrm{b}}$ & 3.7 \\
\hline $28^{\circ} \mathrm{C}$ & & $5.3( \pm 0.3)^{\mathrm{a}}$ & $2.7^{\mathrm{b}}$ & 2.6 \\
\hline Sodium hypochlorite & $7^{\circ} \mathrm{C}$ & $6.2( \pm 0.3)^{\mathrm{a}}$ & $4.3^{\mathrm{b}}$ & 1.9 \\
\hline $28^{\circ} \mathrm{C}$ & & $5.6( \pm 0.3)^{\mathrm{a}}$ & $3.2^{\mathrm{b}}$ & 2.4 \\
\hline \multicolumn{5}{|l|}{ Stainless steel } \\
\hline Peracetic acid & $7^{\circ} \mathrm{C}$ & $6.3^{\mathrm{a}}( \pm 0.3)$ & $3.1^{\mathrm{b}}$ & 3.2 \\
\hline $28^{\circ} \mathrm{C}$ & & $5.6( \pm 0.2)^{\mathrm{b}}$ & $2.8^{\mathrm{b}}$ & 2.8 \\
\hline Sodium hypochlorite & $7^{\circ} \mathrm{C}$ & $6.1^{\mathrm{a}}( \pm 0.2)$ & $3.4^{\mathrm{b}}$ & 2.7 \\
\hline $28^{\circ} \mathrm{C}$ & & $5.8( \pm 0.2)^{\mathrm{b}}$ & $3.2^{\mathrm{b}}$ & 2.6 \\
\hline
\end{tabular}

* in relation to the counts found in control assay.

Values followed for the same letters in each row differ significantly $(\mathrm{p}<0.05)$ according to the Student $\mathrm{t}$ test. 


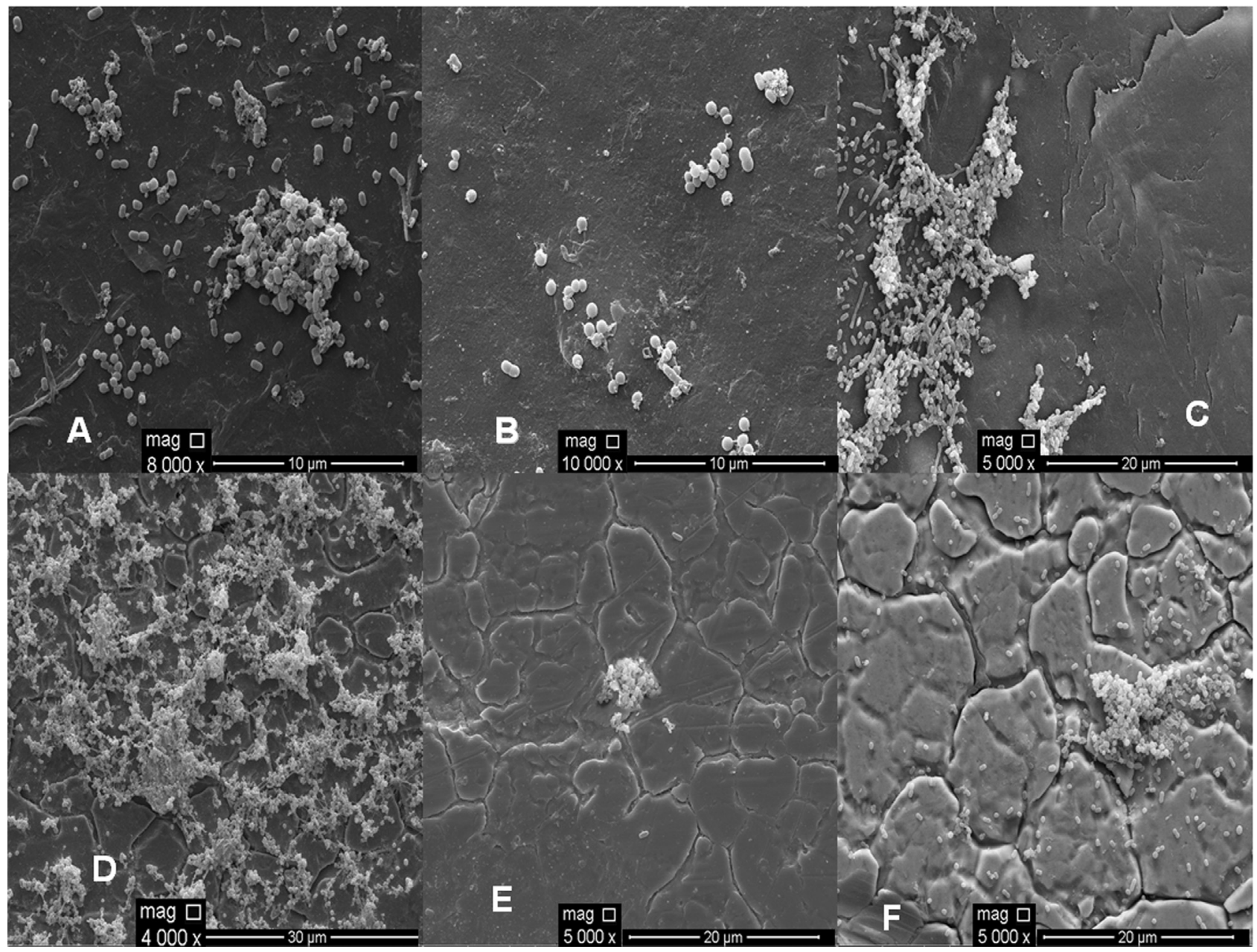

Figure 4 - Scanning electronic microphotography of S. aureus $\mathrm{S} 3$ cells adhered on polypropylene (A, B, C) and stainless steel (D, E, F) when incubated in meat-based broth at $28^{\circ} \mathrm{C}$ for 15 days, after the application of water (A, D - control), peracetic acid (B,E) and sodium hypochlorite (C, F). Different magnifications were used for better visualization.

ent sanitization procedures designed to decrease cells in a biofilm matrix.

\section{Acknowledgments}

The authors are grateful to CNPq (Conselho Nacional de Desenvolvimento Científico e Tecnológico, Brazil) for the scholarship of the first author, and to CETENE (Centro de Tecnologia do Nordeste, Recife, Brazil) for the technical support in electronic microscopy analysis.

\section{References}

Ammor S, Chevallier I; Laguet A; Labadie J; Tallon R; Dufour E (2004) Investigating of the selective bactericidal effect of several decontaminating solutions on bacterial biofilms including useful, spoilage and/or pathogenic bacteria. Food Microbiol 21:11-17.

Asséré A, Oulahal N, Carpentier B (2008) Comparative evaluation of methods for counting surviving biofilm cells adhering to a polyvinyl chloride surface exposed to chlorine or drying. J Appl Microbiol 104:1692-1702.
Barnes LM, Lo MF, Adams MR, Chamberlain AHL (1999) Effect of milk proteins on adhesion of bacteria to stainless steel surfaces. Appl Environ Microbiol 65:4543-4548.

Braga LC, Shupp JW, Cummings C, Jett M, Takahashi JÁ, Carmo LS, Chartone-Souza E, Nascimento AMA (2005) Pomegranate extract inhibits Staphylococcus aureus growth and subsequent enterotoxin production. $\mathrm{J}$ Ethnopharmacol 96:335-339

Bruhn JB, Hagensen JAJ, Bagge-Ravn D, Gram I (2006) Culture conditions of roseobacter strain 27-4 affect its attachment and biofilm formation as quantified by real-time PCR. Appl Environ Microbiol 72:3011-3015.

Carson CF, Mee BJ, Riley TV (2002) Mechanism of action of Melaleuca alternifolia (Tea tree) oil on Staphylococcus aureus determined by time-kill, lysis, leakage, and salt tolerance assay and electron microscopy. Antimicrob Agents Chemother 46:1914-1920.

Cheng G, Zhang Z, Chen S, Bryers JD, Jiang S (2007) Inhibition of bacterial adhesion and biofilm formation on zwitterionic surfaces. Biomaterials 28:4192-4199.

Costerton JW, Steward PS, Greenberg EP (1999) Bacterial biofilms: a common cause of persistent infections. Science 284:1318-1322. 
Downes FP, Ito K (2001) Compendium of methods for the microbiological examination of foods. American Public Health Association (APHA), Washington.

Fux CA, Wilson S, Stoodley P (2004) Detachment characteristics and oxacillin resistance of Staphylococcus aureus biofilm emboli in an in vitro catheter infection model. J Bacteriol 186:4486-4491.

Heydorn A, Nielsen AT, Hentzer M, Stenberg C, Givskov M, Esbol BK, Molin S (2000) Quantification of biofilm structures by the novel computer program COMSTAT. Microbiol 146:2395-2407.

Herrera JJR, Cabo ML, González A, Pazos I, Pastoriza L (2007) Adhesion and detachment kinetics of several strains of Staphylococcus aureus subsp. aureus under three different experimental conditions. Food Microbiol 24:585-591.

Kumar C, Anand SK (1998) Significance of microbial biofilms in food industry: a review. Int J Food Microbiol 42:9-27.

Kusumaningrum HD, Riboldi G, Hazeleger WC, Beumer RR (2003) Survival of foodborne pathogens on stainless steel surfaces and cross-contamination to foods. Int $\mathrm{J}$ Food Microbiol. 85:227-236.

Kuzman L, Rózalski M, Walenka E, Rózalska B, Wysokinska H (2007) Antimicrobial activity of diterpenoids from hairy roots of Salvia sclarea L.: salvipisone as a potential antibiofilm agent active against antibiotic resistant Staphylococci. Phytomed 14:31-35.

Malheiros OS, Passos CT, Casarin LS, Serraglio L, Tondo EC (2010) Evaluation of growth and transfer of Staphylococcus aureus from poultry meat to surfaces of stainless steel and polyethylene and ther disinfection. Food Cont 21:298-301.

Marques SC, Rezende JGOS, Alves LAF, Silva BC, Alves E, Abreu LR; Piccoli RH (2007) Formation of biofilm by Staphylococcus aureus on stainless steel and glass surfaces and its resistance to some selected chemical sanitizers. Braz J Microbiol 38:538-543.

Meira QGS, Barbosa IM, Athayde AJAA, Siqueira-Júnior JP, Souza EL (2012) Influence of temperature and surface kind on biofilm formation by Staphylococcus aureus from foodcontact surfaces and sensitivity to sanitizers. Food Cont 25:469-475.

Meyer B (2003) Approaches to prevention, removal and killing of biofilms. Int Biodeter Biodegrad 51:249-253.

Midelet G, Carpentier B (2002) Transfer of microorganisms, including Listeria monocytogenes, from various materials to beef. Appl Environ Microbiol 68:4015-4024.

Møretro T, Hermansen L, Holck AL, Sidhu MS, Rudi K, Langsrud S (2003) Biofilm formation and the presence of the intercellular adhesion locus ica among Staphylococci from food and food processing environments. Appl Environ Microbiol 69:5648-5655.
Morton LHG, Greenway DIA, Gaylarde CC, Surman SB (1998) Consideration of some implications of the resistance of biofilms to biocides. Int Biodeter Biodegrad 41:247-259.

Oulahal N, Brice W, Martial A, Degraeve P (2008) Quantitative analysis of survival of Staphylococcus aureus or Listeria innocua on two types of surfaces: Polypropylene and stainless steel in contact with three different dairy products. Food Cont 19:78-185.

Revol-Junelles AM, Miguindou-Mabiala R, Roger-Maigne D, Milliere JB (2005) Behavior of Escherichia coli cells and Bacillus cereus spores on poplar wood crates by impedance measurements. J Food Prot 68:80-84.

Rode TM, Langsrud S, Holck A, Moretro T (2007) Different patterns of biofilm formation in Staphylococcus aureus under food-related stress conditions. Int J Food Microbiol 116:372-383.

Ronner AB, Wong ACL (1993) Biofilm development and sanitizer inactivation of Listeria monocytogenes and Salmonella typhimurium on stainless steel and buna-n rubber. J Food Prot 56:750-758.

Rose L, Jensen B, Peterson A, Banerjee SN, Arduino MJ (2004) Swab materials and Bacillus anthracis spore recovery from nonporous surfaces. Emerging Infect Dis 10:1023-1029.

Rossoni EMM, Gaylarde CC (2000) Comparison of sodium hypochlorite and peracetic acid as sanitizing agents for stainless steel food processing surfaces using epifluorescence microscopy. Int J Food Microbiol 61:81-85.

Spoering AL, Lewis K (2001) Biofilms and planktonic cells of Pseudomonas aeruginosa have similar resistance to killing by antimicrobials. J Bacteriol 183:6746-6751.

Srey S, Jahid IK, Ha SD (2012) Biofilm formation in food industries: A food safety concern. Food Cont 31:572-585.

Van Houdt R, Michiels CW (2010) Biofilm formation and the food industry, a focus on the bacterial outer surface. J Appl Microbiol 109:1117-1131.

Vanderzant C, Splittsstoesser DF (1992) Compendium of methods for the microbiological examination of foods. American Public Health Association (APHA), Washington.

Wirtanen G, Ahola W, Mattila-Sandholm T (1995) Evaluation of cleaning procedures in elimination of biofilm from stainless steel surface in process equipment. Food Bioprod Process 73:9-16.

Zoltai PT, Zottola EA, Mckay LL (1981) Scanning electron microscopy of microbial attachment to milk contact surfaces. J Food Prot 44:204-208.

Zottola EA, Sasahara KC (1994) Microbial biofilms in the food processing industry - Should they be a concern? Int J Food Microbiol 23:125-148.

All the content of the journal, except where otherwise noted, is licensed under a Creative Commons License CC BY-NC. 